Offices' Association 1939-40, and he served as a member of the Governmental Committee to review Income Tax Treatment of Superannuation and Pension Schemes in 1950; many annuitants have reason to be grateful for the improvement in the tax position of annuities brought about as a result of the recommendations of this Committee and it is not too much to assume that this improvement is probably largely due to his influence. Among the honorary positions he occupied were those of Actuary to the British Legion Prince of Wales' Pension Fund and Actuary to the Royal United Kingdom Beneficent Association. As a member of the committee of this latter organization he took a keen practical interest in the management of its homes for the elderly.

He was a man of deep religious faith, to which he was always willing to give practical expression. Having family connexions with the ministry of the Methodist Church, he was in early life a member of that Church, acting frequently as a lay preacher. In 1934 he took a prominent part in the formation of the Methodist Sacramental Fellowship, of which he was Honorary Secretary until 1949, since when, until his death, he was a VicePresident. The Society had for one of its main objectives reunion with the Anglican Church, and its influence in moulding Methodist opinion has undoubtedly helped towards the conversations on reunion now taking place between those two churches. After going to reside in the village of Fawkham in 1938, he was confirmed into the Church of England and later became a Churchwarden of the Parish. During his period of office, the interior of the Norman Parish Church was restored and beautified, in the organizing of which he played a prominent part.

In 1913 he married Ada Elizabeth Sharp, a gifted lady who had the distinction of having a picture, which she painted when she was 78 , hung in the Royal Academy. She predeceased him by two years. These two years were marred for him not only by grief for her loss, but by persistent ill-health and much physical suffering which were borne, as those who knew him would expect, with patience and fortitude. He dicd on 11 March 1969 and so passed from our scene a loyal and talented son of the Institute, who in his lifetime worthily carried out the principles enshrined in her Baconian Motto.

V. W. TYLER

\title{
WILLIAM ROBERT MOORE
}

WILliam ROBERT MOORE died on 5 March 1969 at the age of 76 . He commenced his career in 1909 with the Norwich Union Life but in 1914 he transferred to the Phoenix, with which Company he remained to the end of his business life.

His Phoenix career was soon interrupted by the outbreak of the First World War during which he served in France with distinction, gaining the Military Cross in 1916 for great gallantry in leading a bombing party. Later he was wounded in the leg during the Battle of the Somme.

After the War, Moore resumed his service in the Phoenix mortgage department and also his actuarial studies, becoming a Fellow of the Institute in 1920. In 1923 his career took on a wider aspect, leading to his transfer to the Bristol branch of the Phoenix in 1927 where he served for nearly seven years, first as Assistant Manager and then as Manager. In 1934 he returned to London in the more conventional role of Assistant Actuary and became Life Manager and Actuary in the following year. This position he held for twelve years until his appointment as Deputy General Manager in 1947 and he remained as the second executive officer of the Phoenix until his retirement in 1956.

Moore served for two periods on the Council of the Institute-1938-41 and 1943-49. He was a member of the Actuaries Club (Chairman 1951-53) and also of the Gallio and Fellowship Clubs. He was a founder member of the latter and President in 1938. 
Of Moore's relatively few 'outside' interests one recalls his abiding affection for cricket although his migration from Hove to Beaconsfield a few years ago gave him less opportunity for watching County matches.

The foregoing is mainly a catalogue of achievements but the real impact of Bill Moore was as a warm-hearted human being. His colleagues, whether senior or lowly, were his friends. He did not mince his words when he considered that the occasion demanded plain spcaking but, having said his piece, that was the end of the matter. The next time the individual on the 'receiving end' met W. R. M. he could be sure of a cheery smile that was sincere.

Bill Moore was essentially a family man. During the last war he and his wife suffered a grievous blow by the loss of one of their sons on an operational flight with R.A.F. Bomber Command.

His wife survives him together with their three other sons and one daughter.

N. C. BERRY

\section{HENRI AUTERBE}

ThE Institut des Actuaires Français, by the death of Henri Auterbe, has lost its distinguished Président d'Honneur. Auterbe, who died on 7 August 1968, reached the advanced age of 88. He was well known by many British actuaries, having been elected a Corresponding Member of the Institute in 1938, and became an Honorary Overseas Member when this class of membership was recently introduced.

In his tribute to Auterbe, the President of the French Institut records a varied and interesting career. Auterbe became a chemical engineer on completing his formal education, and began with a post in a sugar refinery and then in the gas industry. It was only in 1907, when he was already 27 years old, that he embarked on an actuarial carcer. He entered the Ministère du Travail by competitive examination and was appointed to the office formed in that year to control private insurance. In 1908 he gained the Diploma of the French Institut, and in 1913 became Membre Agrégé (Fellow).

From 1913 onwards he served in l'Union-Vie, one of the important Life companies in France, and became its General Manager in 1939. On the nationalization of the large Life companies in 1947, he became President-General Manager and retired two years later. However, his professional advice continued to be sought and he took an active interest in actuarial matters for many more years.

At the time of the Eleventh International Congress of Actuaries, a memorable Congress held in Paris in 1937, Auterbe was Secretary General of the Institut and it was natural that he should be elected as one of our Corresponding Members in the following year. He became President in 1942. His enthusiasm for international contacts was sustained, and he made further friends among our members when he attended the Centenary celebrations in 1948 and spoke at the Banquet. The fiftieth anniversary of the French Institut was celebrated in 1949 (the actual anniversary having occurred during the war) and a strong delegation was sent by the Institute, led by Sir George Maddex as President. A translation of Auterbe's account of the origins and progress of actuarial science in France, which formed part of his address of welcome, appears in J.I.A. 57, 76.

The resumption of International Congresses in 1951, after a break of no less than 14 years due to the war, brought Auterbe a new generation of actuarial friends. He was a member of the Council of the Permanent Committee for International Actuarial Congresses (now the International Actuarial Association) until 1961. At the informal gatherings which followed the meetings of the Council another facet of Auterbe's versatile accomplishments was revealed. In his early days he had perfected his rendering 